\title{
The Projection from the Superficial to the Deep Layers of the Superior Colliculus: An Intracellular Horseradish Peroxidase Injection Study in the Hamster
}

\author{
Richard D. Mooney, Michael M. Nikoletseas, Paul R. Hess, Zebetta Allen, Anne C. Lewin, and Robert W. \\ Rhoades \\ Department of Anatomy, University of Medicine and Dentistry of New Jersey, School of Osteopathic Medicine, and \\ Robert Wood Johnson Medical School, Piscataway, New Jersey 08854
}

Intracellular recording and horseradish peroxidase (HRP) injection techniques were employed to examine the projections of superficial layer [stratum griseum superficiale (SGS) and stratum opticum (SO)] superior collicular (SC) neurons in the hamster that sent axon collaterals into the deep laminae (those ventral to the SO) of this structure. Sixty-nine neurons were studied, selected from a sample of over 185 HRP-filled superficial layer cells on the basis of having heavily stained axons. Of the 69 cells included in the study, $43.4 \%$ $(n=30)$ sent at least one axon collateral to the deep laminae. Not all cell types in the superficial layers contributed equally to this interlaminar projection: $78.6 \%(n=11)$ of the recovered wide-field vertical cells, $55.0 \%(n=11)$ of the narrow-field vertical cells, $16.7 \%(n=2)$ of the stellate cells, $40.0 \%(n=2)$ of the marginal cells, $18.2 \%(n=2)$ of the horizontal cells, and $28.6 \%(n=2)$ of neurons we could not classify on the basis of their somadendritic morphology projected to the deep layers. Within a given cell class, there were no significant morphological or physiological differences between the neurons that possessed deep axon collaterals and those that did not.

The deep axon collaterals of most of the interlaminar projection neurons were restricted to the stratum griseum intermediale (SGI). In this layer, the largest segment of the axon arbor was located lateral to a projection line that was orthogonal to the SC surface and that passed through the soma of the cell in question.

These results, along with those of a previous study (Mooney et al., 1984), which demonstrated that the dendrites of deep layer cells may extend through the SO and into the SGS, indicate that there is an extensive anatomical substrate by which sensory information may be communicated from superficial to deep layer SC neurons.

An issue of considerable interest to sensory physiologists concerned with the organization of the midbrain is the rolc of the different laminae of the superior colliculus $(\mathrm{SC})$ in the various

\footnotetext{
Received June 23, 1987; revised Sept. 28, 1987; accepted Sept. 29, 1987.

Thanks to Patti Vendula for typing the manuscript. This work was supported in part by Grants E404170 and BNS 85-00142.

Correspondence should be addressed to Dr. Robert W. Rhoades, Dept. of Anatomy, UMDNJ-SOM, 675 Hoes Lane, Piscataway, NJ 08854.

Copyright (C) 1988 Society for Neuroscience $0270-6474 / 88 / 041384-16 \$ 02.00 / 0$
}

functions thought to involve this structure (cf. Wurtz and Albano, 1980; Huerta and Harting, 1984). Over 15 years ago, the behavioral experiments of Casagrande et al. (1972) and Casagrande and Diamond (1974) indicated that the superficial and deep SC laminae might be involved in very different visual functions. In brief, they demonstrated that lesions that destroyed only the superficial laminae of the tree shrew's SC affected pattern discriminations, while those that also involved the deep layers produced an additional profound visual neglect. They interpreted these results as indicating that the superficial and deep SC laminae might be considered as 2 distinct brain structures. There are also other data that are consistent with such a distinction. It is well known (see Edwards, 1980, for a review) that the morphology, receptive-field properties, and projections of neurons in the superficial SC laminae [the stratum opticum (SO) and the laminae dorsal to it] are very different from those of the intermediate and deep layers of this structure [the stratum griseum intermediale (SGI) and the laminae ventral to it].

Another argument that has been used in support of this dichotomy between the superficial and deep SC laminae is that conventional neuroanatomical techniques have failed to convincingly demonstrate connections between these 2 portions of the colliculus (see Edwards, 1980, for a discussion of these data). Recent intracellular recording and injection experiments have shown, however, that the substrate for communication between the superficial and deep SC laminae may be more extensive than previously thought. While Golgi studies (e.g., Victorov, 1966; Tokunaga and Otani, 1976) have shown that some SGI cells send dendrites into the $\mathrm{SO}$, the recent results of Mooney et al. (1984) have indicated that these dendritic projections are much more extensive than were previously demonstrated. Grantyn et al. (1984) have also employed an in vitro preparation to demonstrate that some superficial layer cells have axons that descend in to the deep laminae. Unfortunately, their findings were limited by the fact that the receptive-field properties of these neurons could not be tested and their axonal projections were not fully reconstructed.

In the present study, we have used intracellular recording and HRP injection techniques to further investigate the projections of superficial SC neurons to the deep laminae of this structure. Our aims in these experiments were to (1) provide an estimate of the percentage of superficial layer cells that send axon collaterals into the deep laminae, and (2) define the physiological and morphological cell types that give rise to these projections. 


\section{Materials and Methods}

All of the techniques employed in the present study have been described in several recent reports (Mooney et al., 1985; Rhoades et al., 1986, 1987). They will be recapitulated only briefly in this section.

Animal preparation. The injected cells in this study were selected (see below) from a series of 251 male and female hamsters (age 3-9 months) in which we have carried out intracellular recording and injection experiments over the last 4 years. The basic preparation for all of these animals was uniform. Each animal was anesthetized with sodium pentobarbital $(60 \mathrm{mg} / \mathrm{kg}$, i.p., along with $0.15 \mathrm{ml}$ of a $1.5 \%$ solution of atropine sulfate). The trachea was then cannulated and heart-rate recording leads were fixed to the chest. The hamster was then placed in a stereotaxic headholder that left the visual field free of obstruction, the cortex overlaying the SC was exposed bilaterally, and a cisterna magna puncture was also made. Eyelids were retracted, the pupils dilated with homatropine hydrobromide, and the corneas were protected with repeated applications of mineral oil. All wound edges were infiltrated with a long-lasting local anesthetic (Nupercaine), and the animal was then paralyzed with gallamine triethiodide (initial dose, $40 \mathrm{mg} / \mathrm{kg}$, i.p.). Artificial respiration was carried out according to the table of Freminet et al. (1972), and paralysis and anesthesia were maintained for the duration of the recording experiment with periodic injections of gallamine triethiodide and sodium pentobarbital.

We have verified that our anesthetic regimen is effective by using it in hamsters that were not paralyzed. Such animals sit quietly and are behaviorally unresponsive to any peripheral stimulation. During the course of each recording session, hamsters were also allowed to recover from paralysis and the level of anesthesia was evaluated. In the rare instances when additional, supplemental anesthesia was required, it was provided at this time.

Visual stimulation and response properties analyzed. For most of the cells included in this study, visual receptive-field properties were tested with a projection-type stimulator that was comprised of a projector, shutter, and mirrors that were mounted on galvanometers. This system was controlled by an Apple II computer. In later experiments, a cathode ray tube-based system (Picasso) was employed for visual stimulation. Each cell was tested for responsivity and response sign to flashed spots, speed selectivity, directional selectivity, and the existence of a "silent" suppressive receptive-field surround according to methods that have been stated in detail in a number of previous reports (Chalupa and Rhoades, 1977; Rhoades and Chalupa, 1980; Mooney et al., 1985).

Recording, electrical stimulation, and HRP injection. SC neurons were recorded with micropipettes $(0.4-1.0 \mu \mathrm{m}$ tips) that were pulled from Radnotti Starbore capillaries and filled with 6\% HRP (Sigma VI) in $0.05 \mathrm{M}$ Tris buffer and $0.3 \mathrm{M} \mathrm{KC1}$. They were beveled to resistances of 70-110 M . Electrodes were coupled to a Eutectics Model 400A preamplifier, the output of which was fed to an audiomonitor and storage oscilloscope. Action potentials were also converted to standard pulses for the construction of peristimulus time histograms (PSTHs) by a Cambridge Instruments CED 1401 that was interfaced to an IBM PC. All rcsponses were evaluated in detail extracellularly and retested soon after the neuron was impaled.

Concentric bipolar stimulating electrodes were positioned at a number of different locations in the series of experiments that contributed cells to the sample. Stimulation sites included the spinal cord, trigeminal brain-stem complex, optic chiasm (OX), dorsal lateral geniculate (dLGN) and lateral posterior (LP) nuclei, and SC contralateral to that from which recordings were made. The spinal, SC, LP, and dLGN electrodes were used to define the projections of collicular neurons (cf. Rhoades et al., 1986, 1987; Nikoletseas et al., 1987) and the trigeminal and OX electrodes were employed to delineate inputs to recorded cells (Mooney and Rhoades, 1987). Shocks ( $50 \mu \mathrm{sec}$, isolated from ground) from these electrodes ranged from 0.05 to $2.0 \mathrm{~mA}$ in intensity. All stimulation sites were verified histologically.

Collicular cells were impaled by advancing the electrode and passing brief $(250 \mathrm{msec})$, positive $(1 \mathrm{nA})$ current pulses. HRP was injected by passing $250 \mathrm{msec}$ positive current pulses of 2-4 nA for 2-5 min. The responses of the cell were tested during the course of the injection and, if possible, at its termination.

Perfusion, tissue processing, and reconstruction of HRP-filled neurons. No more than $8 \mathrm{hr}$ after the first attempted injection, hamsters were perfused transcardially according to the method described by Mooney et al. (1985). After 12-60 hr of postfixation, the brain was removed and a block containing the $\mathrm{SC}$ and all stimulation sites was sectioned in the coronal plane (100 $\mu \mathrm{m}$ sections) and processed for the demonstration of diaminobenzidine (DAB) reaction product according to the protocol described by Semba et al. (1983). Tissue was plated from a $2 \%$ gelatin solution onto subbed slides, air-dried, dehydrated in absolute ethanol, cleared in xylene, and coverslipped. Sections containing stimulation sites were all counterstained with cresyl violet.

All cells were reconstructed at a total magnification of $720 \times$, using a $40 \times$ planapochromatic objective and a drawing tube. Laminar boundaries were identified, in most instances, simply by viewing the section with dark-field optics (Fig. 1). In a small number of cases, laminar borders determined in this fashion were cross-checked by counterstaining sections with thionin after the cells were reconstructed.

Cross-sectional areas of cell bodies, dendritic trees, and deep (i.e., ventral to the $\mathrm{SO}$ ) axons were computed from the reconstructions with the aid of a graphics tablet. Values reported are means \pm standard deviations.

\section{Results}

A total of 69 HRP-filled superficial layer cells comprised the database for this report. They were selected from a sample of over 185 such neurons on the basis of the intensity of the staining of their axons. Only those cells in which a dense HRP reaction product was visible in the parent axon, secondary branches, and terminal swellings were included in the analysis. In our experience, axonal filling is the most variable aspect of the labeling observed after intrasomatic HRP injection. We believe that selection of cells on this basis provides the best available estimate of the percentage of superficial lamina neurons within a given morphological class that project to the deep layers.

\section{Cell types recovered and percentages with deep-going axons}

As in our previous report (Mooney et al., 1985), we divided superficial layer SC cells into 5 classes. These groups follow, fairly closely, those defined by Langer and Lund (1974) for the superficial laminae of the rat's SC and include marginal cells, stellate cells, narrow-field vertical cells, wide-field vertical cells, and horizontal cells. Marginal cells have small ( $<80 \mu \mathrm{m}^{2}$ area) cell bodies located at or just below the tectal surface and their dendrites descend into the stratum griseum superficiale (SGS) and upper SO. Stellate cells also have relatively small $\left(<90 \mu \mathrm{m}^{2}\right.$ area) somata and spherical dendritic arbors that generally extend no more than $200 \mu \mathrm{m}$ away from the cell body. Narrow-field vertical cells have vertically oriented dendritic arbors that extend no more than $300 \mu \mathrm{m}$ in either the rostrocaudal or mediolateral planes. The average soma area for these neurons is $90-100 \mu \mathrm{m}^{2}$. Wide-field vertical cells have relatively large (125$150 \mu \mathrm{m}^{2}$ ) cell bodies and dendritic arbors that may extend for up to $1 \mathrm{~mm}$ in the mediolateral plane. Horizontal cells have their somas either just below the SC surface or at the border between the SGS and SO. Their cell bodies (usually about 100 $\mu \mathrm{m}^{2}$ in area) are generally fusiform, and the extent of their dendritic arbors may reach $1.5 \mathrm{~mm}$. The relative percentages of these different cell types in our sample and the percentage of each type with deeply projecting axons are provided in Figure 2 . There was also a small number $(n=7 ; 10.1 \%$ of the total sample) of neurons that we could not classify according to this scheme. These are also included in Figure 2.

Not all morphological classes of superficial layer cells were equally likely to have axonal projections to the deep layers: $78.6 \%(n=11)$ of the wide-field vertical cells we recovered and $55.0 \%(n=11)$ of the narrow-field vertical cells had deep projections. Only $16.7 \%(n=2)$ of the stellate cells and $18.2 \%(n=$ 2 ) of the horizontal cells had deep axons; $40 \%(n=2)$ of the marginal cells and $28.6 \%(n=2)$ of the neurons that we could not classify projected to the deep laminae. A chi-square analysis 

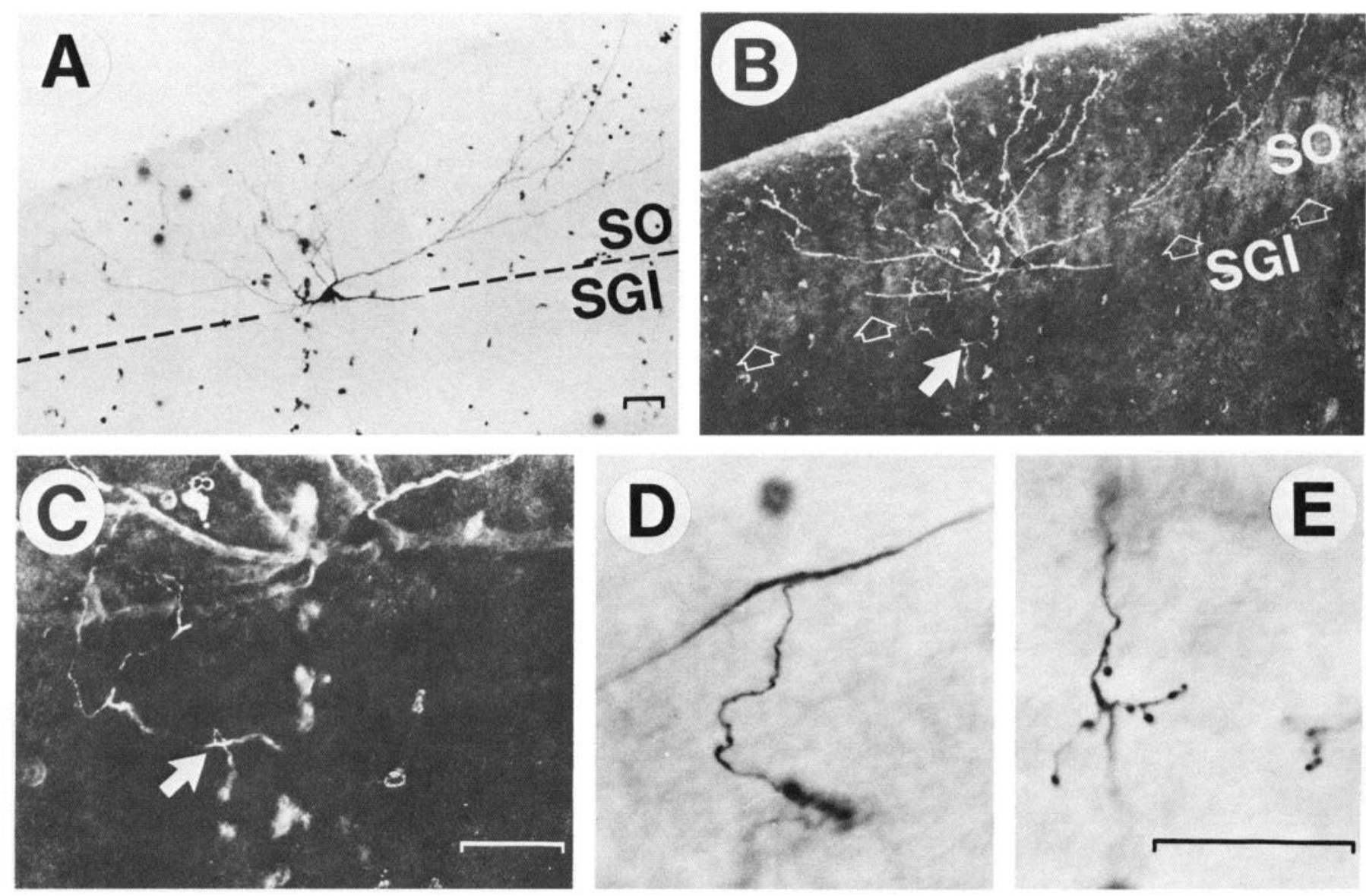

Figure 1. Example of a recovered cell and the manner in which the boundary between the SO and SGI can be visualized with dark-field optics. $A$, Bright-field photomicrograph of a wide-field vertical cell that had its cell body in the lowermost SO. $B$, Dark-field photomicrograph of the same neuron. Open arrows denote the SO-SGI border; note the transition from the lighter, fibrous region $(\mathrm{SO})$ to the darker, predominantly cellular region (SGI). The solid arrow points to a portion of the cell's axon that is clearly in the SGI. C, Higher-power photomicrograph of the region denoted by the solid arrow in $B . D, E$, Portions of the deep axon of the cell. The photographs were taken with the same $40 \times$ planapochromatic objective used for our reconstructions. $D$, A secondary collateral coming off the parent axon. $E$, A small cluster of terminal boutons. Calibration: $100 \mu \mathrm{m}(A-C) ; 25 \mu \mathrm{m}(D, E) . F$, Reconstruction of the cell in $A-E$. The thick, solid line is the SC surface and the thinner, dashed line denotes the SO-SGI border. Note that the axonal collateralization in the deep layers is almost lateral (to the left) of the cell body. Calibration, $100 \mu \mathrm{m}$.

of these data indicated that these differences were statistically significant (chi-square $=15.1, d f=5, p<0.01$ ).

\section{Receptive-field properties of recovered cells}

We have followed, with minor modification, the schema of Albano et al. (1978) in classifying recovered cells according to their physiological properties. The categories we used were stationary-responsive (S-R), movement-sensitive (M-V), and directionally selective (D-S). Responses characteristic of each of these classes are illustrated in Figure 3 and percentages of cells in each class are summarized in Figure $4 A$.

Stationary-responsive cells (Fig. $3 A$ ) gave responses (generally

\section{Table 1. Summary of morphological properties of SC neurons included in this study}

\begin{tabular}{|c|c|c|c|c|c|}
\hline & \multicolumn{2}{|c|}{ A. Wide-field vertical cells } & \multicolumn{2}{|c|}{ B. Narrow-field vertical } & \multirow{2}{*}{$\frac{\text { C. Stellate cells }}{\text { Deep axon }}$} \\
\hline & Deep axon & No deep axon & Deep axon & No deep axon & \\
\hline Soma area $\left(\mu \mathrm{m}^{2}\right)$ & $230.8 \pm 113.5$ & $190 \pm 68.1$ & $129.3 \pm 33.7$ & $138.0 \pm 50.5$ & $180.5 \pm 154.8$ \\
\hline $\begin{array}{l}\text { Distance from soma to SO-SGI } \\
\text { border }(\mu \mathrm{m})\end{array}$ & $220.1 \pm 107.2$ & $158.7 \pm 39.3$ & $275.6 \pm 158.2$ & $265.1 \pm 148.8$ & $224.0 \pm 9.9$ \\
\hline $\begin{array}{l}\text { Dendritic cross-sectional area } \\
\left(\mu \mathrm{m}^{2}\right)\end{array}$ & $187,018 \pm 94,827$ & $150,467 \pm 67,357$ & $25,918 \pm 27,972$ & $33,267 \pm 36,940$ & $186,500 \pm 224,930$ \\
\hline $\begin{array}{l}\text { Deep axon cross-sectional area } \\
\left(\mu \mathrm{m}^{2}\right)\end{array}$ & $84,146 \pm 33,048$ & - & $41,717 \pm 27,130$ & - & $27,550 \pm 30,052$ \\
\hline $\begin{array}{l}\text { Mediolateral symmetry of deep } \\
\text { axonal collateralization }\end{array}$ & $0.71 \pm 0.29$ & - & $0.85 \pm 0.33$ & - & $0.83 \pm 0.25$ \\
\hline
\end{tabular}




was completely lateral to the above-described projection line, and a value of 0 indicates an axon collateralization completely medial to that line. 


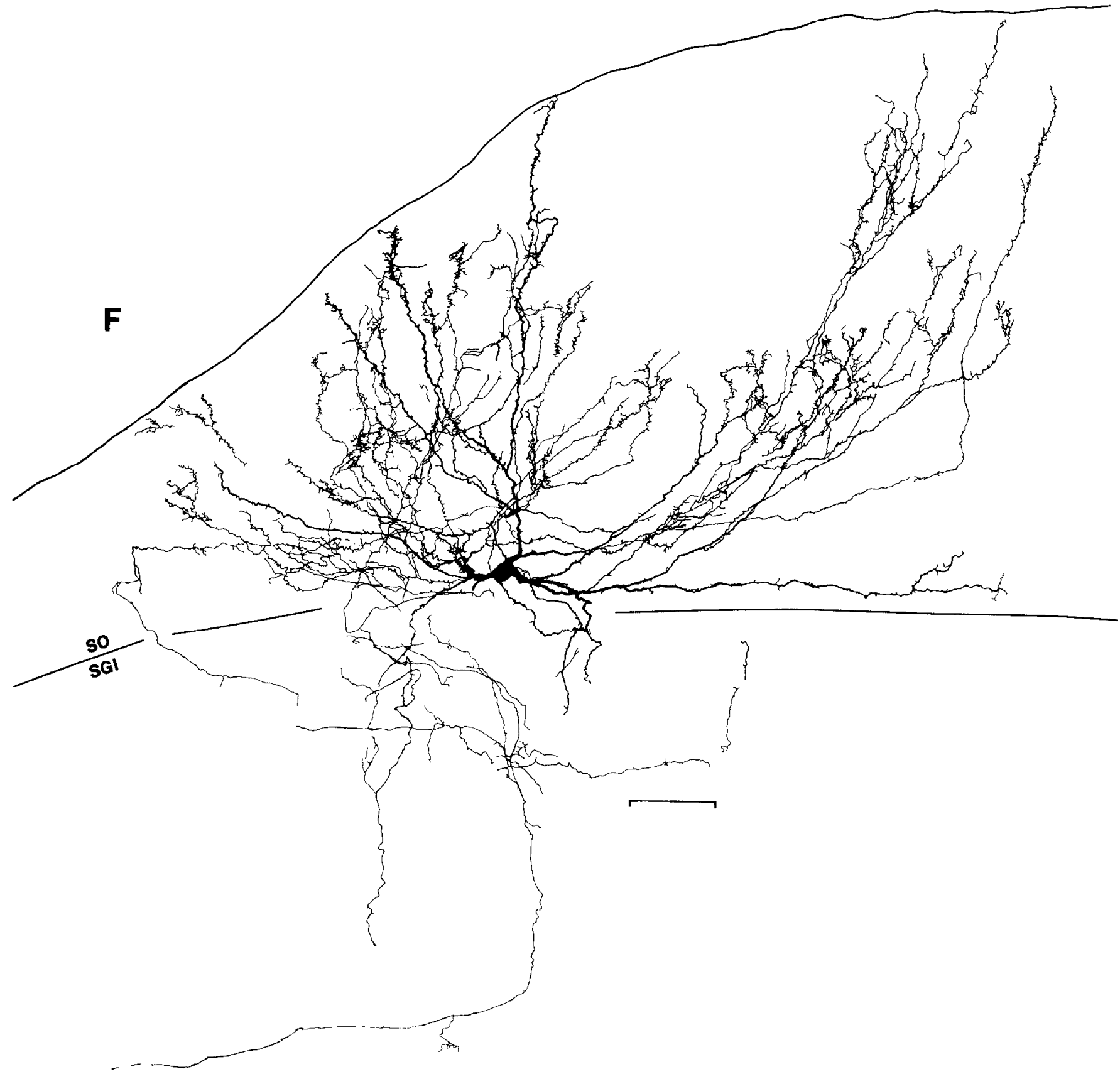

Table 1. Continued

C. Stellate cells

No deep axon

$121.1 \pm 34.1$

$254.2 \pm 134.0$

$16,440 \pm 19,271$

$-$

$-$
D. Marginal cells Deep axon No deep axon

$142.3 \pm 20.5$

E. Horizontal cells

Deep axon

F. Unclassified cells

$\begin{array}{cccc}152.5 \pm 37.5 & 114.3 \pm 37.2 & 290.0 \pm 176.8 & 117.8 \pm 44.9 \\ 197.0 \pm 202.2 & 234.1 \pm 174.1 & 27.0 \pm 38.2 & 225.8 \pm 74.5 \\ 66,200 \pm 9,050 & 68,300 \pm 47,490 & 67,000 \pm 25,597 & 71,940 \pm 22,817 \\ 101,300 \pm 138,310 & - & 98,150 \pm 65,973 & - \\ 0.68 \pm 0.28 & - & 0.59 \pm 0.42 & -\end{array}$



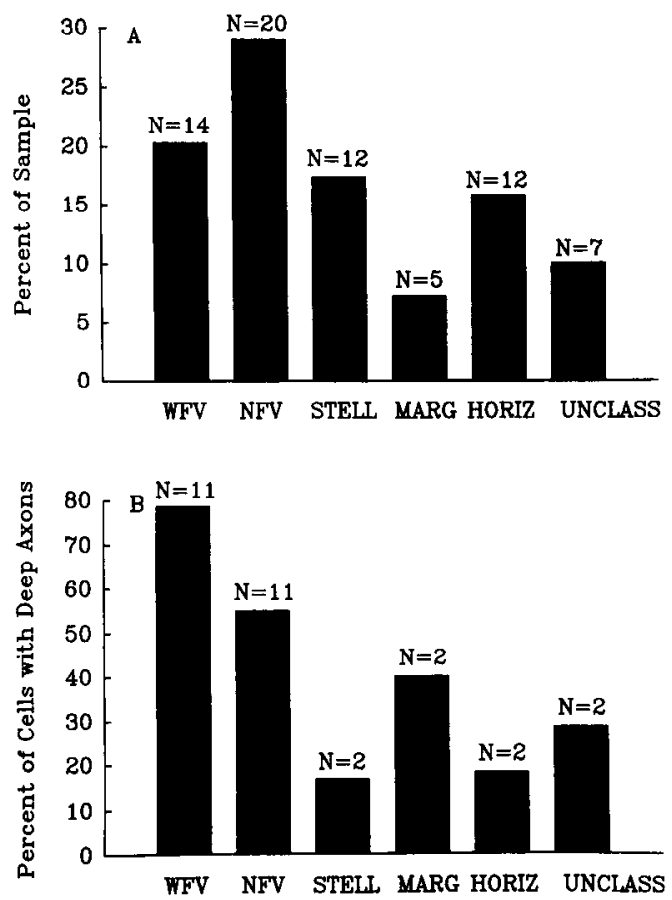

Figure 2. A, Percentages of different morphological cell types in our sample. $W F V$, wide-field vertical cells; $N F V$, narrow-field vertical cells; $S T E L L$, stellate cells; $M A R G$, marginal cells; HORIZ, horizontal cells; UNCLASS, cells that did not fall into any of these groups. The number above each bar denotes the number of cells in each class. $B$, Percentages of cells in each category that sent at least one axon collateral into the deep laminae. The numbers above each bar denote the number of cells within a given class that had such projections. Note that most of the deep-projecting neurons in our sample were either wide-field or narrowfield vertical cells.

on-off) to small, flashed spots of light that were nearly as vigorous as those elicited by moving stimuli. Movement-sensitive cells (Fig. $3 B$ ) responded poorly or not at all to flashed stimuli, but gave strong discharges to small spots that were swept across the receptive field in any direction. Directionally selective cells (Fig. 3C) were movement-sensitive, but also responded such that displacement of a stimulus across the receptive field in at least one direction produced a discharge that exceeded that in the opposing direction by at least a factor of 3 . In addition to visual cells, we also recovered a small number of superficial layer neurons that were either somatosensory or unresponsive.

Overall, there were no significant differences between the distributions of receptive-field types for the neurons that sent axon collaterals to the deep laminae and those that did not (Fig. $4 A$; chi-square $=5.5, d f=4, p>0.05$; incompletely classified cells were not included in this analysis).

\section{Wide-field vertical cells}

The laminar and tangential distributions of the wide-field vertical cells included in our sample are illustrated in Figure $5 \mathrm{~A}$. Most of these neurons had their cell bodies in the lower portion of the SGS or in the SO. A listing of their morphological characteristics is provided in Table $1 \mathrm{~A}$, and their receptive-field types are summarized in Figure $4 B$. Wide-field vertical cells with deep-going axons generally had their somas in the $\mathrm{SO}$, while those without such projections had their cell bodies either in the SGS or at the SGS-SO border. The average soma area for the cells with the deep axons $\left(230.8 \pm 113.5 \mu \mathrm{m}^{2}\right)$ was somewhat larger than that for the other wide-field vertical cells (190.0 \pm $\left.68.1 \mu \mathrm{m}^{2}\right)$, but this difference was not statistically significant $(t=$ $0.58, d f=4, p>0.05)$. The average dendritic cross section of the wide-field vertical cells with deep axons $(187,018 \pm 94,828$ $\mu \mathrm{m}^{2}$ ) was also somewhat greater than that of the cells in this class that did not project to the deep laminae $(150,467 \pm 67,357$ $\mu \mathrm{m}^{2}$ ). This difference also failed to achieve statistical significance $(t=0.61, d f=4, p>0.05)$.

Wide-field vertical cells with deep axon collaterals are illustrated in Figures 1 and 6. Detailed morphology of the deep axon collaterals of these neurons is documented photographically in Figures 1 and 7 . Of the 11 wide-field vertical cells with deep axon collaterals, 7 extended no further than the SGI, 3 possessed collaterals that reached as far as the stratum album intermedium (SAI), and 1 had collaterals in the stratum griseum profundum (SGP). In no case did the collaterals of a given cell pass through one of the deep layers without giving off at least several en passant and/or terminal boutons. All of the wide-field vertical cells that projected to the deep laminae also gave off collaterals in the SGS and/or SO.

Deeply projecting axon collaterals of wide-field vertical cells averaged $84,146 \pm 33,048 \mu \mathrm{m}^{2}$ in their cross-sectional extent and generally arborized laterally to a projection line that was orthogonal to the SC surface and passed through the soma of the parent cell. The portion of the axon arbor's cross-sectional area on either side of such a projection line was calculated for each deeply projecting cell, and the average part of the arbor lateral to the projection line is listed in Table 1A. For the widefield vertical cells, this value was $0.71 \pm 0.29$. The fact that we sectioned all of our material in the transverse plane made it difficult to assess the rostrocaudal organization of axon arbors with accuracy better than $100 \mu \mathrm{m}$ (our section thickness). However, we did not notice any tendency for the deep axon arbors of wide-field vertical neurons to be displaced either rostrally or caudally from the parent cell.

With the exception of a single somatosensory neuron, all of the wide-field vertical cells in our sample were exclusively visual (Fig. $4 B$ ). There appeared to be a difference between the distributions of visual receptive-field types for the wide-field vertical cells that had deep-going axons and those that did not. Nearly $37 \%(n=4)$ of the former cells were D-S, while none of the neurons in the latter category exhibited this response property. Overall, however, there were no statistically significant differences between the distributions of response properties for the wide-field vertical cells that projected to the deep laminae and those that did not (chi-square $=2.5, d f=3, p>0.05$ ).

\section{Narrow-field vertical cells}

The laminar and tangential distributions of the narrow-field vertical cells included in our sample are illustrated in Figure $5 B$. The physiological and morphological characteristics of the narrow-field vertical cells included in the sample are summarized in Figure $4 C$ and Table $1 \mathrm{~B}$, respectively. Most (81.3\%) of these cclls were exclusively visual, and the majority of these were movement-sensitive. There were no significant differences between the narrow-field vertical cells with deep axon collaterals and those without such projections with respect to any of the physiological or morphological characteristics that we evaluated.

Two narrow-field vertical cells with deeply projecting axons are illustrated in Figure 8. The deep axon collaterals of one of the narrow-field vertical cells (Fig. $8 A$ ) are documented pho- 

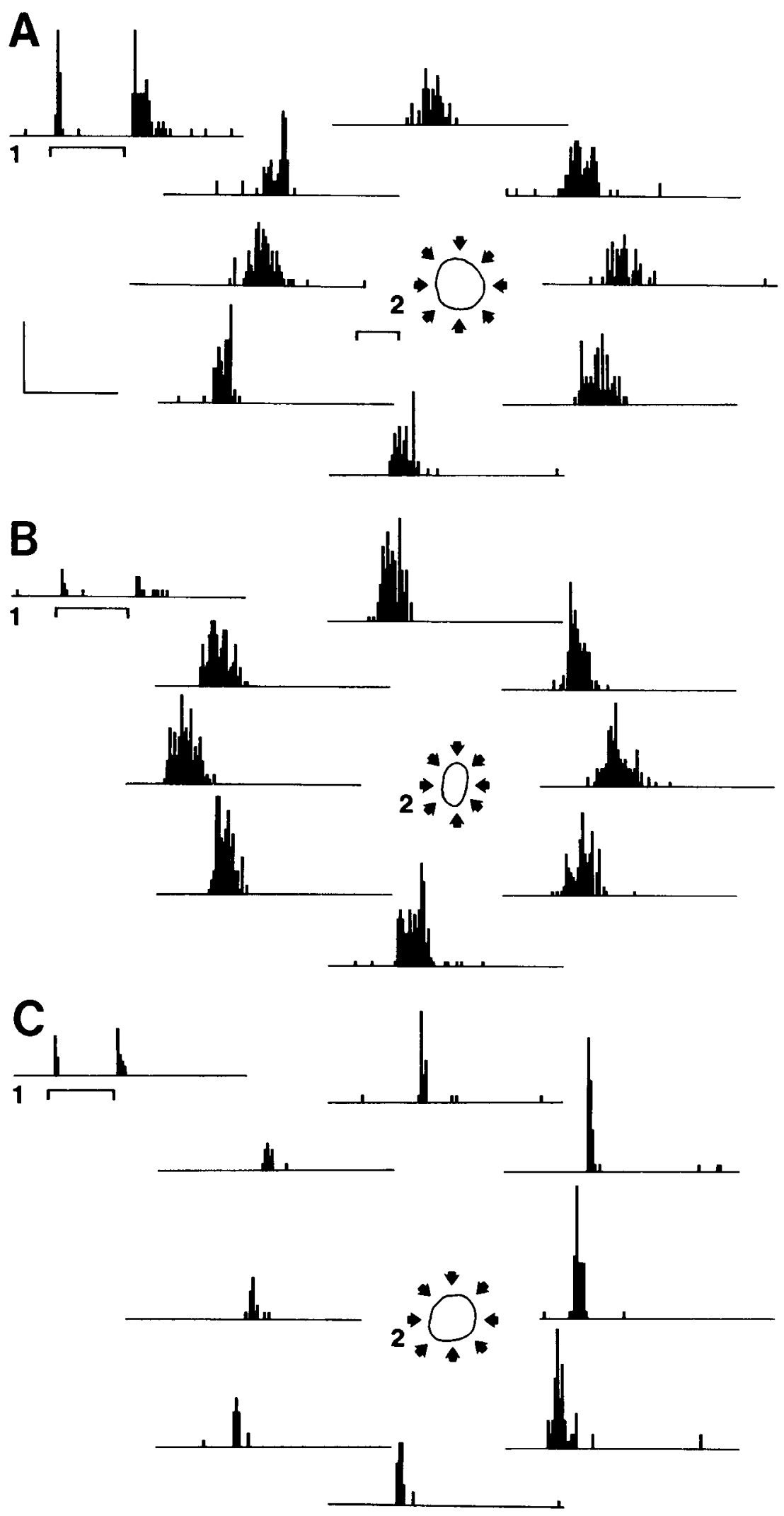

Figure 3. Examples of the responses of each of the 3 classes of visual superficial layer cells. $A$, Responses of an $\mathrm{S}-\mathrm{R}$ cell. 1 , On-off discharge elicited by flashing a $5.8^{\circ}$ spot over the center of the receptive field for 15 trials. The bar under the histogram denotes the stimulus duration; 2 , Discharges evoked by sweeping the same spot across the receptive field 15 times in each of 8 directions (stimulus speed, $26 \% \mathrm{sec}$ ). Note that the response to the flashed stimulus is not significantly weaker than that obtained with the moving spot. $B$, Discharges of an M-V cell. $l$, Relatively weak on-off response obtained with a $5.8^{\circ}$ flashed spot; 2 , the much stronger response that was obtained when the same stimulus was moved across the receptive field (stimulus speed, $31 \% \mathrm{sec}$ ). Note also that the response to the moving spot was about the same regardless of direction. $C$, Responses of a D-S cell. 1 , Weak response to a flashed spot $\left(5.9^{\circ}\right)$; 2 , the highly directional response obtained when the same stimulus was swept across the receptive field (speed, $26 \% \mathrm{sec}$ ). Calibration for the histograms (lower left-hand part of $A$ ), 20 spikes/ $\mathrm{sec}$ and $2.5 \mathrm{sec}$. Calibration for the visual receptive fields, $10^{\circ}$.

tographically in Figure 9. The axonal arborizations of narrowfield vertical cells appeared to fall into 3 distinct classes. The first $(n=11)$ was comprised of cells (e.g., Fig. 10, $A, B)$ with projections that included both the superficial and deep laminae.
The second $(n=4)$ consisted of cells that had widespread local axon collaterals in the superficial laminae, and the third $(n=$ 5) contained neurons with axonal arbors that extended only slightly beyond the confines of the cell's dendritic tree. 
CELLS WITII DEEI AXONS
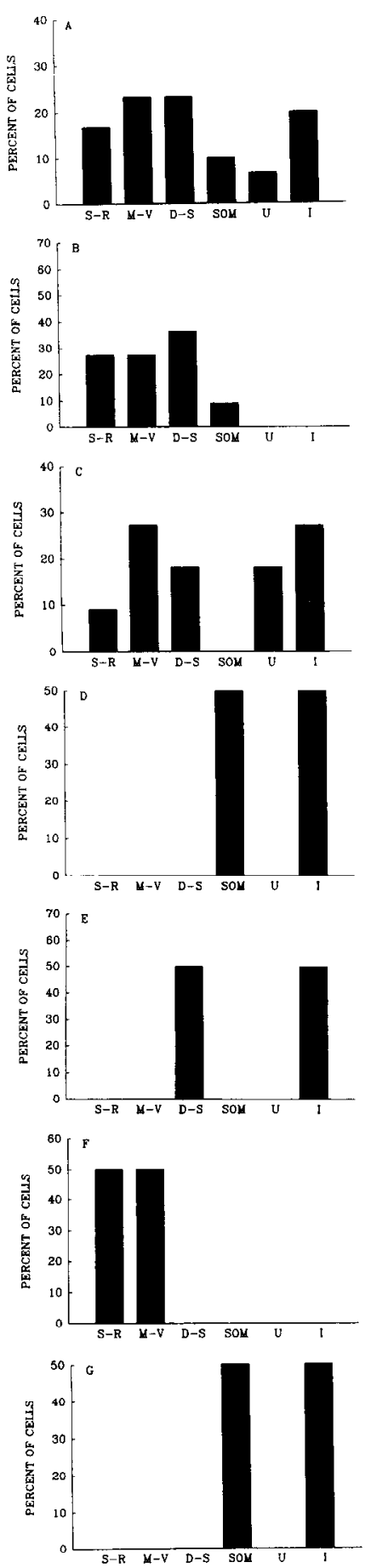

Figure 4. Summary of the physiological properties of the cells included in this study. Data for cells with or without deep axon collaterals have been treated separately. $A$, Summary of the combined data for all morphological cell types. $S$ - $R$, Stationary-responsive; $M-V$, movement-sensitive; $D-S$, directionally selective; $S O M$, somatosensory; $U$, unresponsive; $I$, incompletely classified. $B$, Data for wide-field vertical cells; $C$, for narrow-field vertical cells; $D$, for stellate cells; $E$, for marginal cells; $F$, for horizontal cells; and $G$, for morphologically unclassifiable cells.

The average cross-sectional extent of the deep axonal arborizations of the narrow-field vertical cells was $41,716 \pm 27,130$ $\mu \mathrm{m}^{2}$. In most (63.6\%) cases, the deep axon collatcrals of these neurons were restricted to the SGI, but $36.4 \%$ had collaterals that extended into the SAI and/or SGP. All of the narrow-ficld vertical cells with deep collaterals also gave off boutons in the SGS and SO.

The axon collaterals of the deeply projecting narrow-field vertical cells, like those of the wide-field vertical cells, were displaced laterally to a projection line running through the parent cell body (see Table 1B). The average percentage of the deep arbor that was lateral to a projection line through the cell body was $85.3 \pm 33.5 \%$.

\section{Stellate cells}

The locations of the stellate cells included in our sample are illustrated in Figure $5 \mathrm{C}$. With the exception of one cell whose soma was in the SO, all of these neurons were located in the superficial gray layer. Only 2 of the stellate cells that we recovered sent axon collaterals into the deep laminae. A listing of their morphological properties is provided in Table $1 \mathrm{C}$, along with those of the 10 stellate neurons that did not have axonal terminations in the deep layers. The receptive-field characteristics of the 2 groups of neurons are summarized in Figure $4 D$. The 2 deeply projecting stellate cells were unusual in that one responded only to somatosensory stimuli and the other was unresponsive. All of the completely characterized stellate cells without deep axons were exclusively visual.

One of the 2 stellate cells with a deep axon is illustrated in Figure $10 \mathrm{~A}$. The axon arbors of both of the stellate neurons that innervated the deep layers descended only as far as the SGI. Both of these cells also gave off collaterals in the superficial laminae. The other stellate cells generally had axonal arborizations that extended only slightly beyond their dendritic trees.

\section{Marginal cells}

The somata of all of the marginal cells that we recovered were located (by definition) at or just below the pial surface. The tangential distribution of these neurons is illustrated in Figure $5 D$. Only 5 cells from this class had axonal staining that was sufficiently dark to permit a determination of whether they possessed deep axon collaterals. The physiological characteristics of these neurons are summarized in Figure $4 E$, and their morphological characteristics are listed in Table 1D. Because of the small sample size, it is probably not meaningful to make comparisons between the properties of the marginal cells that projected to the deep laminae and those that did not.

The 2 marginal cells with deep axons are illustrated in Figure $10, B, C$. The descending projections of cells in this category were relatively sparse. In one case (Fig. $10 B$ ), the primary axon descended all the way to the SGP, but gave off only 2 secondary collaterals in the deep layers. In the second instance (Fig. 10C), a secondary collateral was given off in the $\mathrm{SO}$, and another one was visible in the deep layers. Thus, while deep-going axons could be identified for 2 marginal cells, their terminations in the deep laminae appeared to be limited.

\section{Horizontal cells}

The laminar and tangential distributions of the horizontal cells included in our sample are illustrated in Figure $5 E$, and the physiological and morphological properties of these neurons are summarized in Figure $4 F$ and Table 1E. Only 2 of the cells in this class had axonal projections that extended into the deep laminae; one of these is illustrated in Figure 10D. The axonal tcrmination of this cell in the decp laycrs was rclatively sparse when compared with those of either the wide-field or narrow- 


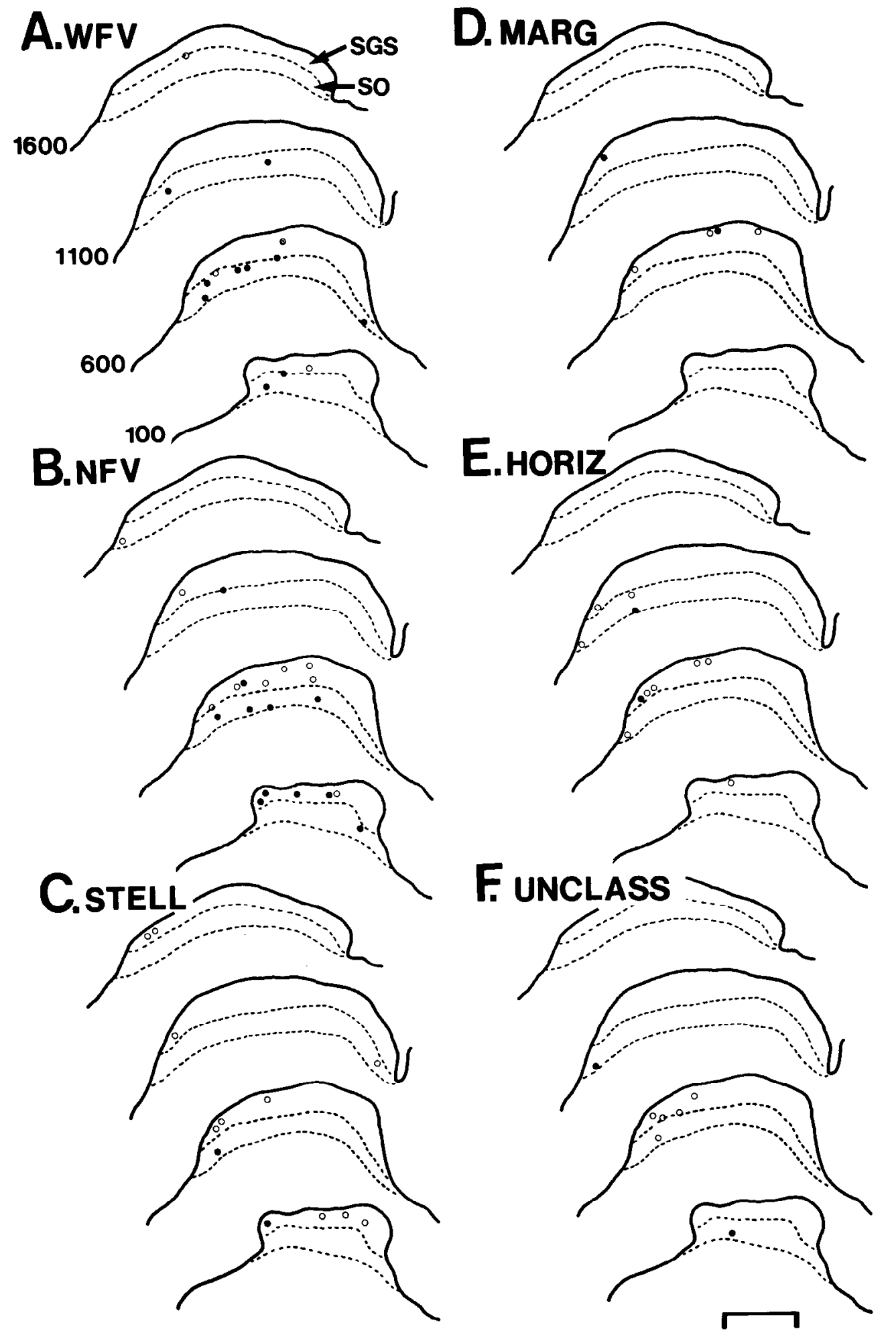

Figure 5. Laminar distribution of the cell bodies of the neurons included in our sample. The locations of these cell bodies filled circles for neurons with deep-going axons, open circles for cells without such projections) are plotted separately for each morphological class. $A$, Distribution for wide-field vertical cells. The sections are spaced at $500 \mu \mathrm{m}$ intervals and the dashed lines denote SGS-SO and SO-SGI borders. $B$, Locations of the narrow-field vertical cells. $C$, Locations of the stellate cells. $D$, Distribution of the marginal cells. $E$, Distribution of the horizontal cells. $F$, Locations of the unclassified neurons. Calibration, $500 \mu \mathrm{m}$. field vertical cells. The remainder of the horizontal cells in our sample had axonal arborizations that were, for the most part, restricted to the layer that contained the parent neuron's cell body. There were no significant differences in either physiological properties or dendritic arbors between the horizontal cells that projected to the deep laminae and those that did not.

\section{Unclassifiable cells}

We recovered 7 cells that did not fit into any of the 5 groups listed above. The laminar and tangential distributions of these neurons are illustrated in Figure $5 F$, their receptive-field properties are summarized in Figure $4 G$, and their morphological 


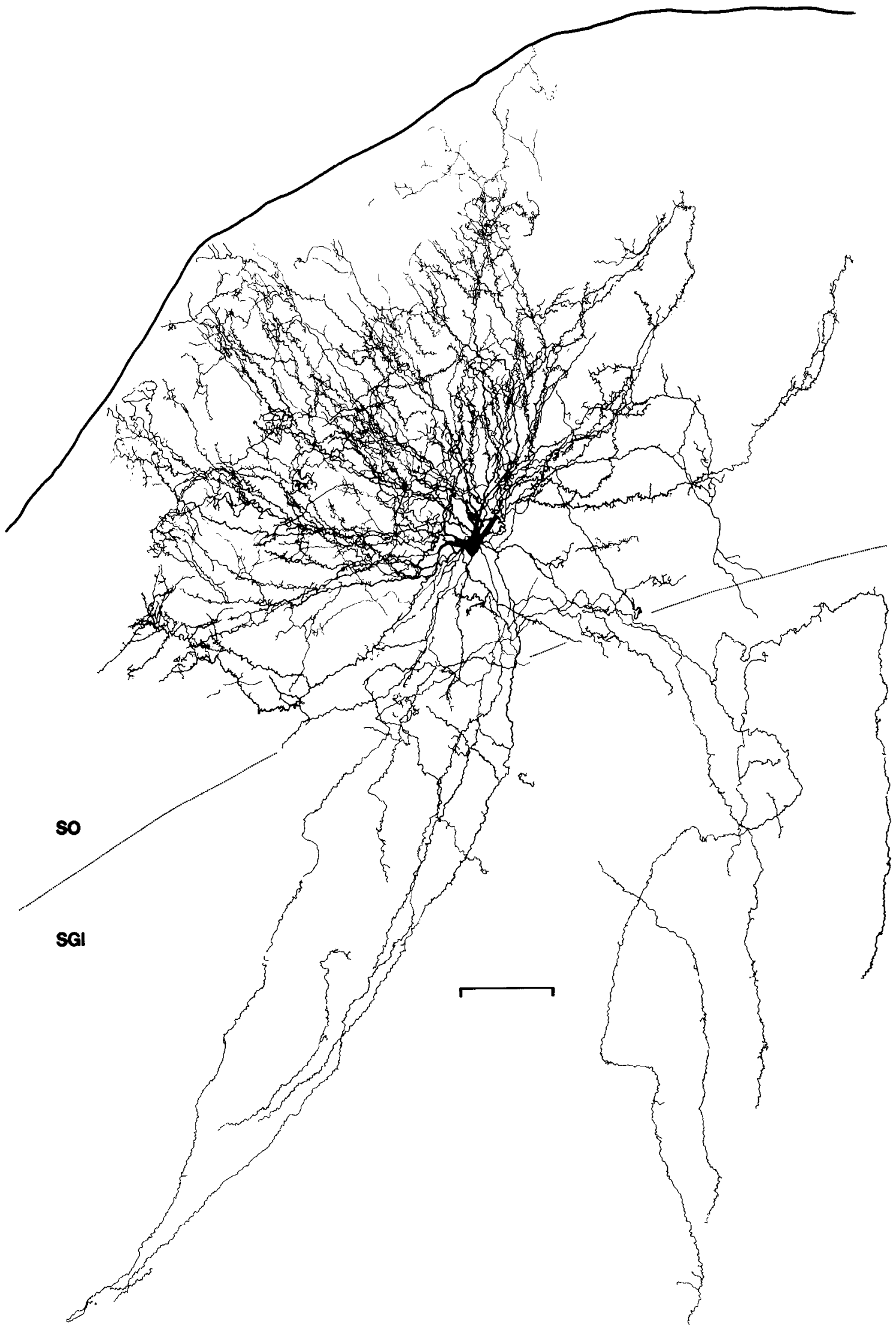

Figure 6. Reconstruction of a wide-field vertical cell with an extensive axonal collateralization in the deep layers. The soma of this neuron was located in the middle SO and its dendrites extended to the pial surface. The axon arose from the cell body and virtually all of the processes ventral to the soma are portions of the axon arbor. It collateralized extensively in the SGS, SO, and SGI. Some axon branches also extended into the SAI and SGP. Only the SO-SGI border (dotted line) and the SC surface (dark, solid line) have been drawn for clarity. Calibration, $100 \mu \mathrm{m}$. 

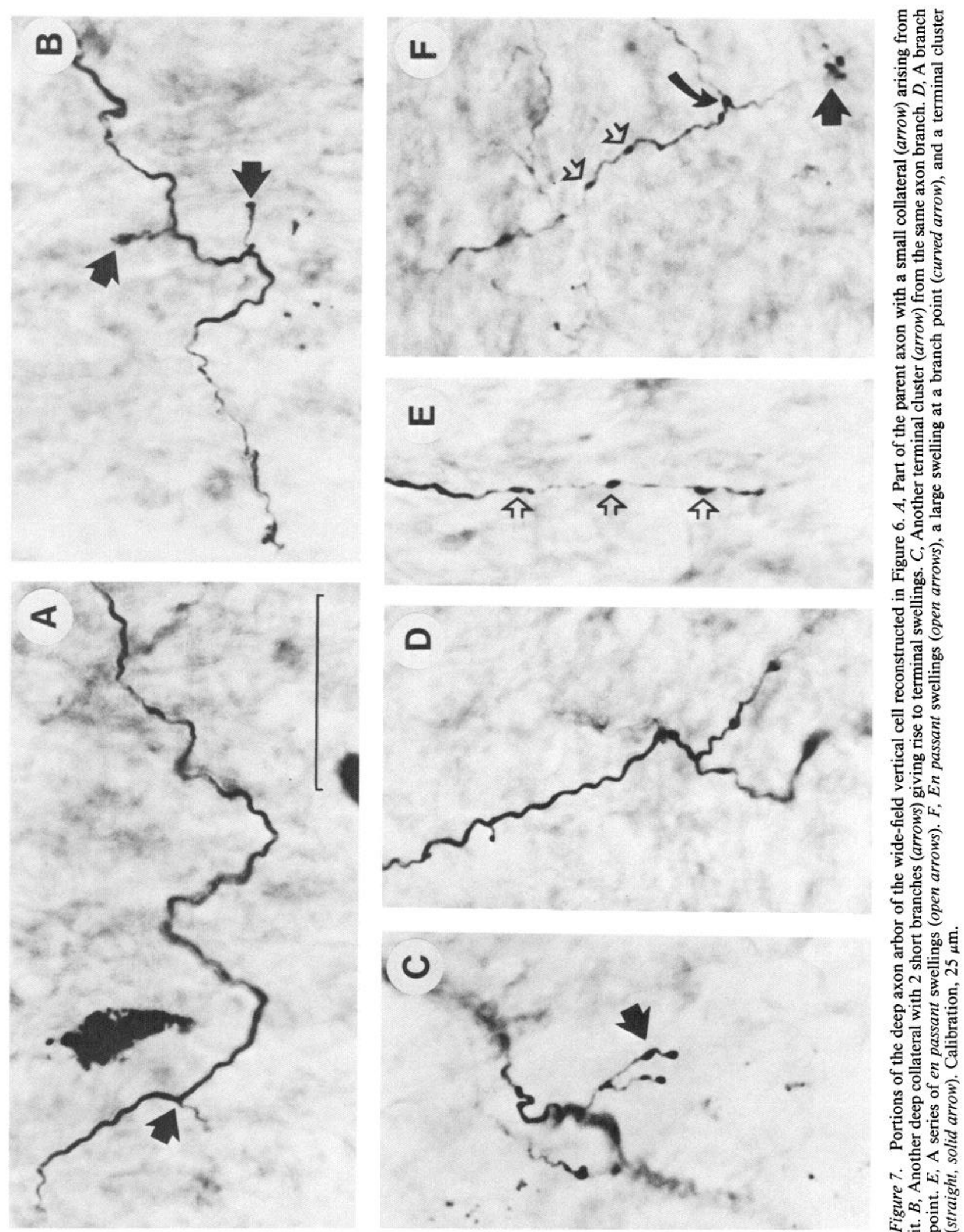


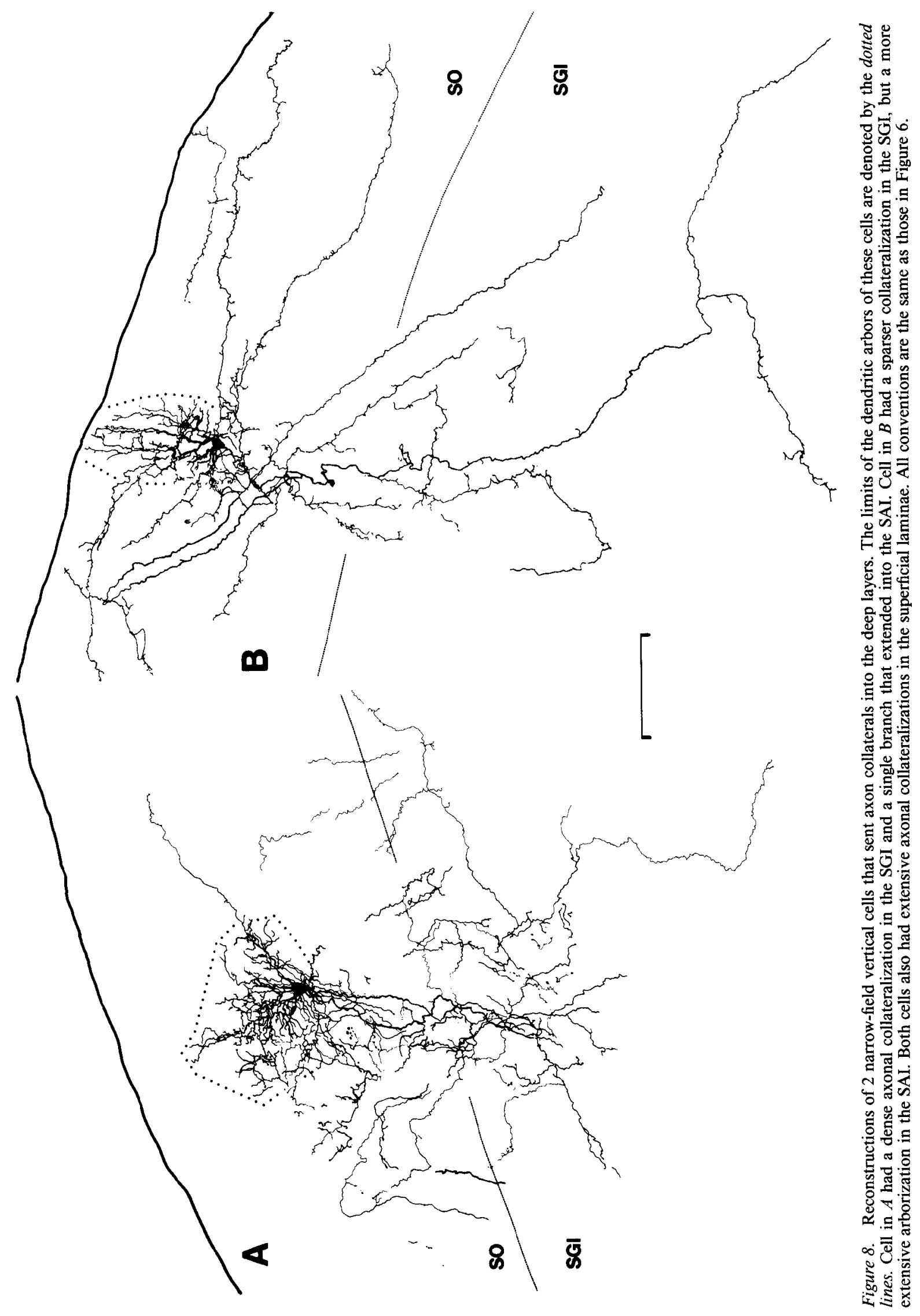



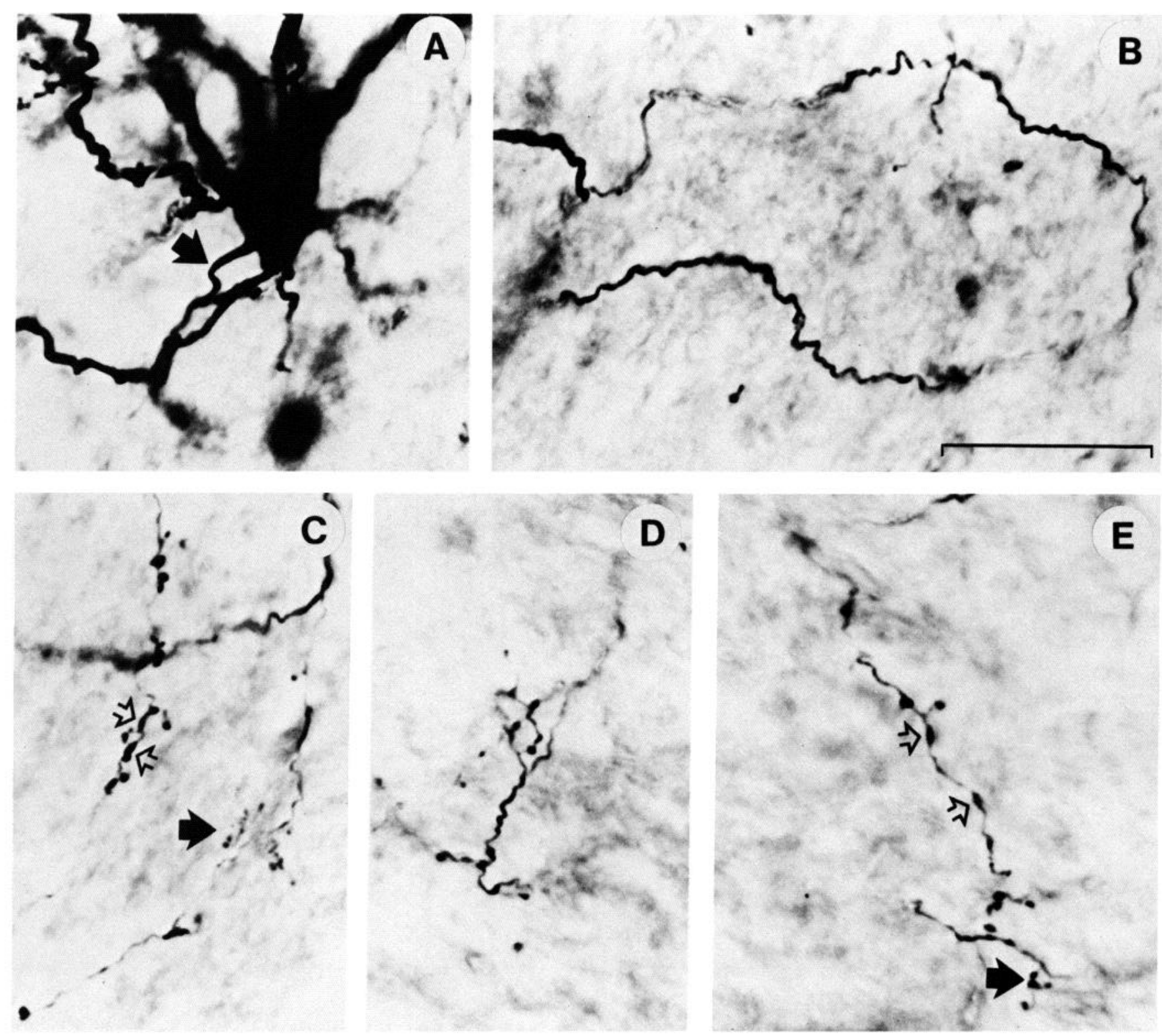

Figure 9. A, Cell body of the narrow-field vertical cell reconstructed in Figure 8A. Solid arrow points to the cell's axon. B, "Loop" in the axon that straddles the SO-SGI border. $C-E$, En passant (open arrows) and terminal (solid arrows) swellings given off in the deep layers by this cell's axon. Calibration, $25 \mu \mathrm{m}$.

characteristics are listed in Table $1 \mathrm{~F}$. Two of the neurons in this group had axons that descended through the deep laminae, but neither collateralized extensively in these layers.

\section{Summary}

Our data demonstrate that a substantial number of cells in the superficial laminae of the hamster's SC send axon collaterals to the deep laminae. They show, further, that not all cell types in these layers contribute equally to this interlaminar projection. Three-fourths of the wide-field vertical cells and about one-half of the narrow-field vertical cells had interlaminar projections. Very few stellate, marginal, or horizontal cells had deep projections, and the terminal arbors of those that did were relatively sparse. Within a given cell class, there were no morphological or physiological features that distinguished interlaminar cells from neurons that did not possess such projections.

\section{Discussion}

Over $43 \%$ of the superficial layer SC cells included in our analysis sent at least one axon collateral into the deep laminae. While this finding clearly supports the conclusion that there is a substantial projection from the superficial to the deep SC layers in the hamster, the limitations of the approach that we employed make it difficult to draw any firm conclusions regarding the total percentage of superficial layer cells that contribute to this pathway. Our data demonstrated that not all cell types in the superficial laminae were equally likely to send axon collaterals to the deep layers. Therefore, in order to know the overall percentage of superficial cells that project to these laminae, one would also be required to estimate the contribution of each of the cell types that we identified to the total neuronal population in the SGS and SO. Such data are currently unavailable. 


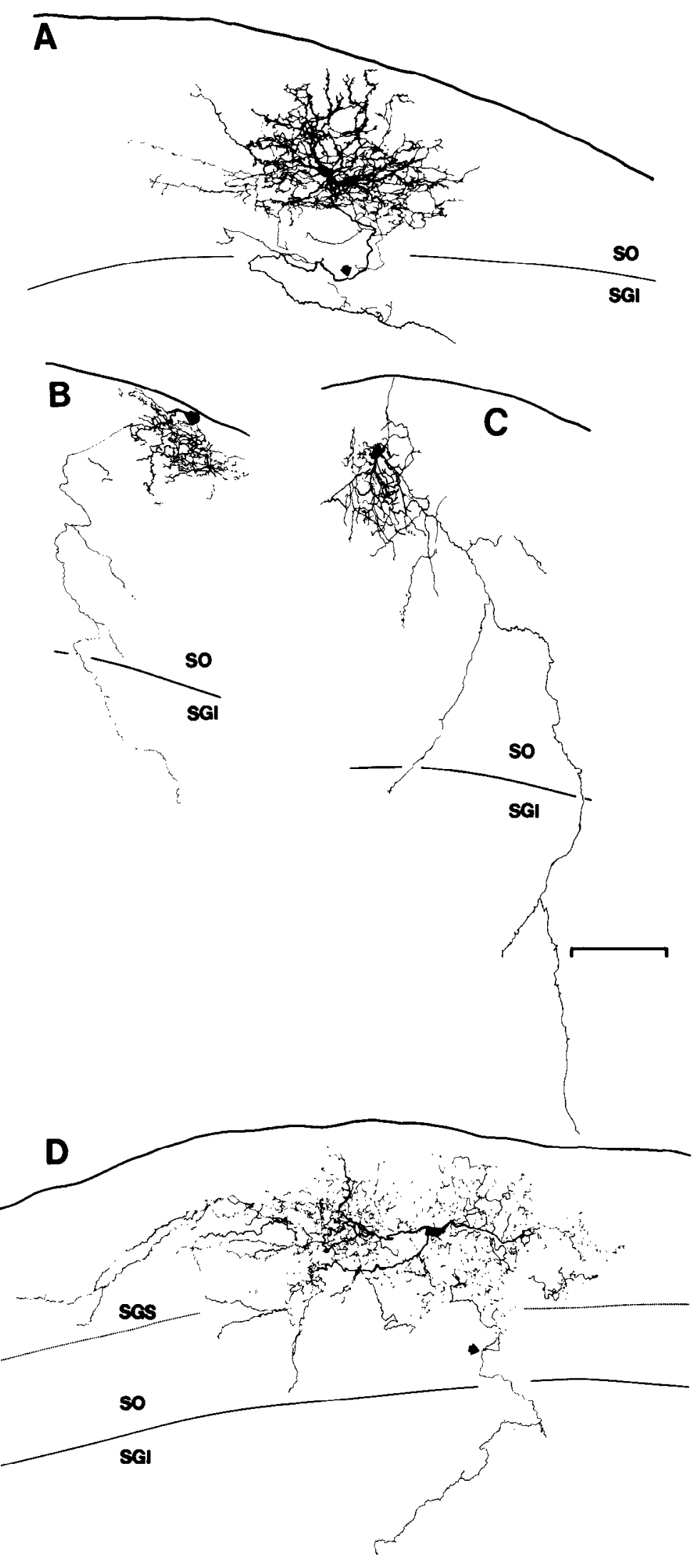

Figure 10. A, Reconstruction of a stellate cell that sent an axon collateral into the SGI. $B, C$, Marginal cells that also innervated this layer. $D$, Horizontal cell

B

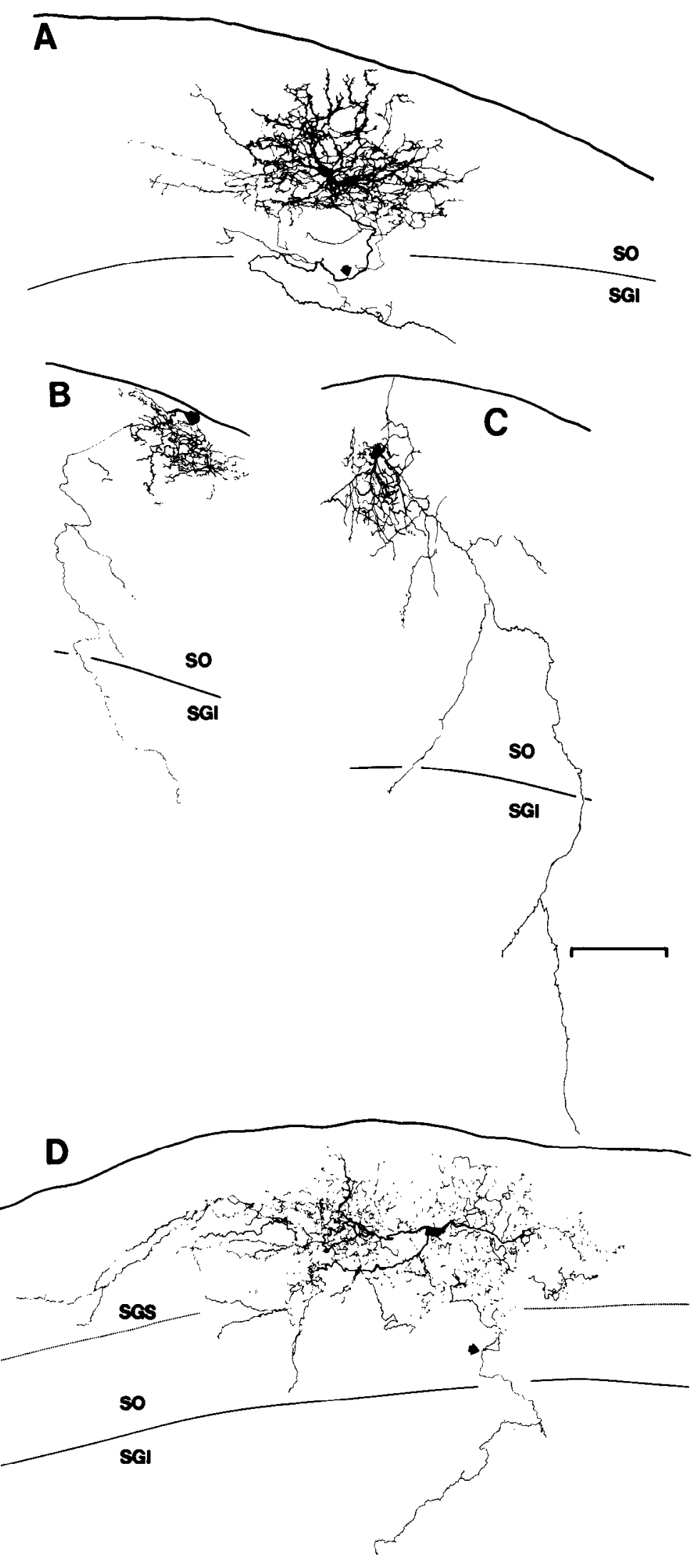
gray layer. All conventions are as in Figure 6. 
A second limitation of the approach we employed is the difficulty of determining whether the termination of visible label indicates the end of the structure of interest or simply a fading of HRP reaction product. Even though we limited our sample to cells with very heavily stained axons, it is likely that incomplete axonal filling has caused us to underestimate, at least slightly, the percentage of superficial layer cells with deep-going axons.

\section{Relationship of the current study to previous anatomical} results

This report is not the first to suggest the existence of SGS and SO neurons with axons that descend into the SGI. A number of Golgi studies concerned with the dendritic architecture of superficial layer SC neurons have made mention of axons that descend from the superficial to the deep laminae. Valverde (1973) pointed out that the axons of many superficial layer neurons descended into the deep laminae, but he did not provide any evidence that these fibers gave off synaptic terminals. He also noted that virtually all of the cells that he stained in very young mice had such axons, but that a population of superficial layer neurons with strictly local axon collaterals became apparent in older animals. Langer and Lund (1974) reported that the axons of cells that they referred to as pyramidal may extend into the deep SC laminae, but they provided no details beyond this fact. They also reported that the axons of wide-field vertical cells and a class of neurons referred to as type III ganglion cells may have axons that extend into the deep laminae. Similarly, Tokunaga and Otani (1976) noted that several of the cell types that they encountered in the superficial laminae of the rat's SC had axons that descended into the deep layers. Here again, no information regarding the collateralizations of these fibers was provided. The cell types that possessed such axonal projections in their material included cylindrical neurons (in our terminology, narrow-field vertical cells) and widc-field vertical cells.

Sprague (1975) has also provided anatomical data that suggest that the superficial SC laminae project to the deep layers. He noted that small lesions placed in the outer portion of the SGS produced degeneration in the deep layers and concluded that this result was indicative of interlaminar connections in the SC (however, see Edwards, 1980, for an alternative interpretation).

There are also limited data from previous intracellular injection studies (Takahashi and Ogawa, 1978; Grantyn et al., 1984; Karabelas and Moschovakis, 1985; Moschovakis and Karabelas, 1985) that indicate that some superficial layer SC neurons in rabbit and cat extend axons into the deep layers. Grantyn et al. (1984) illustrated a single "interlaminar" cell in cat that appeared to be a narrow-field vertical cell. Takahashi and Ogawa (1978) showed a wide-field vertical cell that was located in the SO and sent an axon into the SGI. Moschovakis and Karabelas (1985) and Karabelas and Moschovakis (1985) have provided illustrations of 2 SO cells with relatively narrow, vertically oriented dendritic trees that have extensive axonal collateralizations in the deep layers. None of these investigators assessed the receptive-field properties of the $\mathrm{SC}$ neurons that they stained.

In summary, already existing, but limited, anatomical data are consistent with the present results, in that they suggest that some superficial layer SC cells send axons to the deep laminae and that narrow- and wide-field vertical cells appear to predominate among these neurons.

\section{Nature of the deep axonal projections}

The deep axons of superficial layer cells generally gave off collaterals that were restricted to the SGI, and within this lamina there was a relatively consistent relationship between their terminal fields and projection lines that were orthogonal to the SC surface and passed through the parent cell. Most of the terminal arbors of deeply projecting axons, especially those that arose from narrow- and wide-field vertical cells, were lateral to those projection lines. This suggests that a given deep layer neuron would be likely to receive input from supcrficial layer cells that were medial to it. If the input from the superficial to the deep laminae is critical for the organization of the visual fields of deep layer cells (see below for discussion of this issue), the above would, in turn, suggest that visual-field projection lines in the SC should actually curve medially as they extend into the deep SC laminae.

While the clustering of SC visual receptive fields in the superficial laminae has been studied in detail by McIlwain and his collaborators (McIlwain, 1975; Capuano and Mcllwain, 1981), such an analysis has never been undertaken for both the superficial and deep layers. Examination of our own data (R. W. Rhoades, unpublished observations) and those available from other studies in hamster (Drager and Hubel, 1975; Tiao and Blakemore, 1976) provide no strong support for the hypothesis put forward in the preceding paragraph. In this regard, it should be noted that the deep SC laminae are known to receive visual input from a number of sources. Most notable among these are a Y-axon input from the retina that has been demonstrated in both cat (Berson and Mcllwain, 1982) and hamster (Mooney and Rhoades, 1987), and afferents from a number of visual cortical areas that have been documented in a variety of species (e.g., Krieg, 1947; Garey et al., 1968; Kawamura et al., 1974; Baleydier et al., 1983; Benzinger and Massopust, 1983; Segal and Beckstead, 1984; Lynch et al., 1985).

\section{Visual information conveyed from the superficial to the deep laminae}

The responses of the superficial layer neurons that projected to the deep laminae were not significantly different from those of the cells that did not. There appeared to be a preponderance of D-S neurons among those with deep-going axons, but this was not a statistically significant finding. It would thus appear that the same kind of sensory information that the superficial layers provide to their other projection targets is also conveyed to the deep laminae. In fact, some of the interlaminar cells also had extracollicular projections to the posterior thalamus (Nikoletseas et al., 1987).

At present, the manner in which the superficial-to-deep layer projection influences the responses of deep layer cells is not known, and the use of local inactivation or ablation techniques to address this question would be technically difficult. There are, however, data that suggest the possibility that this pathway may not provide the most important visual input to deep layer neurons. Stein (1978; also Stein and Arigbede, 1972) has demonstrated that cooling the posterior neocortex in cat decreases the visual responses of deep layer neurons, and Ogasawara et al. (1984) and Hardy and Stein (1986) have demonstrated that essentially the same effect can be obtained by cooling or ablation 
of the posterior suprasylvian cortex. This result is consistent with findings that strongly suggest that deep layer visual cells in this species receive an indirect $\mathrm{Y}$ input from this cortical region (Berson and McIlwain, 1982; Berson, 1985). In monkey (Schiller et al., 1974) and ground squirrel (Michael, 1971), cortical inactivation or cooling completely abolishes the visual responses of deep layer SC neurons. On the other hand, the visual responsivity of deep layer $\mathrm{SC}$ cells in hamster and rabbit does not depend on visual cortex. Removal of virtually all the posterior neocortex in either species does not significantly alter the visual responses of deep layer neurons (Stewart et al., 1973; Chalupa and Rhoades, 1977; Finlay et al., 1978; Rhoades and Chalupa, 1978; Graham et al., 1982).

\section{Implications of these findings with respect to collicular organization}

Our data indicate clearly that one of Edwards' (1980) arguments for treating the superficial SC laminae as one structure and including the deep layers with the "reticular core" of the brain stem is not correct. We have provided strong evidence for 2 ways in which sensory processing in the superficial laminae may be communicated to deep layer neurons. The first, of course, is through the axonal projections described in this paper. The second is by means of the extension of the dendrites of many deep layer cells into the SGS and SO (Mooney et al., 1984). Like the deep-going projections of superficial layer cells, the latter finding was anticipated by the results of several Golgi studies concerned with the dendritic morphology of deep layer cells (e.g., Victorov, 1966; Tokunaga, 1970; Tokunaga and Otani, 1976) and was confirmed by other intracellular recording and HRP injection studies in the cat (Karabelas and Moschovakis, 1985; Moschovakis and Karabelas, 1985).

Several other relatively recent experiments have provided additional data that suggest that it is probably most appropriate to consider all SC laminae together as a single structure. For example, there are now data that indicate that the retino-SC projection is not limited to the superficial laminae (Berson and McIlwain, 1982; Beckstead and Frankfurtcr, 1983; Mooncy and Rhoades, 1987). Mooney and Rhoades (1987) have shown further that individual retinal axons with $\mathrm{Y}$-like receptive-field properties innervate both the superficial and deep SC laminae in the hamster.

Retrograde tracing experiments have also shown that a number of SC output pathways include both superficial and deep layer neurons (e.g., Hashikawa and Kawamura, 1977; Edwards and Henkel, 1978; Magalhaes-Castro et al., 1978; Mower et al., 1979; Graham and Berman, 1981; Holcombe and Hall, 1981).

Thus, while it is clear that there is a partition of the superficial and deep SC laminae in terms of a number of their anatomical connections and the functional characteristics of many of their cells, there is also ample evidence of inputs to, and outputs from, this structure that cut across the boundary between the superficial and deep layers. These findings, when considered together with the growing body of evidence concerning the anatomical substrate for interlaminar transfer of sensory information in this structure, suggest to us that many aspects of SC organization are best understood when this midbrain nucleus is considered as a single structure.

\section{References}

Albano, J. E., A. L. Humphrey, and T. T. Norton (1978) Laminar organization of receptive field properties in tree shrew superior colliculus. J. Neurophysiol. 41: 1140-1164.
Baleydier, C., M. Kahungu, and F. Mauguiere (1983) A crossed corticotectal projection from the lateral suprasylvian area in the cat. J. Comp. Neurol. 214: 344-351.

Beckstead, R. M., and A. Frankfurter (1983) A direct projection from the retina to the intermediate gray layer of the superior colliculus demonstrated by anterograde transport of horseradish peroxidase in monkey, cat and rat. Exp. Brain Res. 52: 261-268.

Benzinger, H., and L. C. Massopust (1983) Brain stem projections from cortical area 18 in the albino rat. Exp. Brain Res. 50: 1-8.

Berson, D. M. (1985) Cat lateral suprasylvian cortex: Y-cell inputs and corticotectal projection. J. Neurophysiol. 53: 544-556.

Berson, D. M., and J. T. McIlwain (1982) Retinal Y-cell activation of deep-layer cells in the superior colliculus of the cat. J. Neurophysiol. 47: 700-714.

Capuano, U., and J. T. McIlwain (1981) Reciprocity of receptive field images and point images in the superior colliculus of the cat. J. Comp. Neurol. 196: 13-23.

Casagrande, V. A., and I. T. Diamond (1974) Ablation study of the superior colliculus in the tree shrew (Tupaia glis). J. Comp. Neurol. 156: 207-238.

Casagrande, V. A., J. K. Harting, W. C. Hall, and I. T. Diamond (1972) Superior colliculus of the tree shrew: A structural and functional subdivision into superficial and deep layers. Science $177: 444-447$.

Chalupa, L. M., and R. W. Rhoades (1977) Responses of visual, somatosensory and auditory neurons in the golden hamster's superior colliculus. J. Physiol. (Lond.) 270: 595-626.

Drager, U.C., and D. H. Hubel (1975) Kesponses to visual stimulation and relationship between visual, auditory and somatosensory inputs in mouse superior colliculus. J. Neurophysiol. 38: 690-713.

Edwards, S. B. (1980) The deep cell layers of the superior colliculus: Their reticular characteristics and structural organization. In The Reticular Formation Revisited, J. A. Hobson and M. A. B. Brazier, eds. pp. 193-209, Raven, New York.

Edwards, S. B., and C. K. Henkel (1978) Superior colliculus connections with the extraocular motor nuclei in the cat. J. Comp. Neurol 179: $451-468$.

Finlay, B. L., S. E. Schneps, K. G. Wilson, and G. E. Schneider (1978) Topography of visual and somatosensory projections to the superior colliculus of the golden hamster. Brain Res. 142: 223-235.

Freminet, A., E. Bursaux, and C. Poyart (1972) Mesure de la vitesse de renouvellement du lactate chez le rat par perfusion de ${ }^{14} \mathrm{C}-\mathrm{U}-(\mathrm{L})$ lactate's. Pfleugers Arch. 334: 293-302.

Garey, L. J., E. G. Jones, and T. P. S. Powell (1968) Interrelationships of striate and extrastriate cortex with the primary relay sites of the visual pathway. J. Neurol. Neurosurg. Psychiatry 31: 135-157.

Graham, J., and N. Berman (1981) Origins of the pretectal and tectal projections to the central lateral nucleus in the cat. Neurosci. Lett. 26: $209-214$

Graham, J., and N. Berman, and E. H. Murphy (1982) Effects of visual cortical lesions on receptive-field properties of single units in superior colliculus of the rabbit. J. Neurophysiol. 47: 272-286.

Grantyn, R., R. Ludwig, and W. Eberhardt (1984) Neurons of the superficial tectal gray. An intracellular HRP-study on the kitten superior colliculus in vitro. Exp. Brain Res. 55: 172-176.

Hardy, S. C., and B. E. Stein (1986) Small lesions in suprasylvian cortex produce contralateral visual neglect and a lowered incidence of deep laminae visual cells in the superior colliculus. Soc. Neurosci. Abstr. 12: 1368 .

Hashikawa, T., and K. Kawamura (1977) Identification of cells of origin of tectopontine fibers in the cat superior colliculus: An experimental study with the horseradish peroxidase method. Brain Res. 130: $65-79$.

Holcombe, V., and W. C. Hall (1981) Laminar origin of ipsilateral tectopontine pathways. Neuroscience 6: 255-260.

Huerta, M. F., and J. K. Harting (1984) The mammalian superior colliculus: Studies of its morphology and connections. In The Comparative Neurology of the Optic Tectum, H. Vanegas, ed., pp. 687773, Plenum, New York.

Karabelas, A. B., and A. K. Moschovakis (1985) Nigral inhibitory termination on efferent neurons of the superior colliculus: An intracellular horseradish peroxidase study in the cat. J. Comp. Neurol. 239: 309-329.

Kawamura, S., J. M. Sprague, and K. Niimi (1974) Corticofugal projections from the visual cortices to the thalamus, pretectum, and superior colliculus in the cat. J. Comp. Neurol. 158: 339-362.

Krieg, W. J. S. (1947) Connections of the cerebral cortex. 1. The albino 
rat. C. Extrinsic connections. J. Comp. Ncurol. 86: 267-394.

Langer, T. P., and R. D. Lund (1974) The upper layers of the superior colliculus of the rat: A Golgi study. J. Comp Neurol. 158: 405-436.

Lynch, J. C., A. M. Graybiel, and L. J. Lobeck (1985) The differential projection of two cytoarchitectonic subregions of the inferior parietal lobule of macaque upon the deep layers of the superior colliculus. $\mathbf{J}$. Comp. Neurol. 235: 241-254.

Magalhaes-Castro, H. H., A. D. de Lima, P. E. S. Saraiva, and B. Magalhaes-Castro (1978) Horseradish peroxidase labeling of cat tectotectal cells. Brain Res. 148: 1-13.

McIlwain, J. T. (1975) Visual receptive fields and their images in superior colliculus of the cat. J. Neurophysiol. 38: 219-230.

Michael, C. R. (1971) Visual response properties and functional organization of cells in the superior colliculus of the ground squirrel. Vision Res. 3: 299-308.

Mooney, R. D., and R. W. Rhoades (1987) Axon terminals in hamster superior colliculus from ganglion cells with $\mathrm{x}$-like and $\mathrm{y}$-like receptive field properties. Invest. Ophthalmol. Vis. Sci. Suppl. 28: 123.

Mooney, R. D., and B. G. Klein, M. F. Jacquin, and R. W. Rhoades (1984) Dendrites of deep layer, somatosensory superior collicular neurons extend into the superficial laminae. Brain Res. 324: 361365.

Mooney, R. D. B. G. Klein, and R. W. Rhoades (1985) Correlations between the structural and functional characteristics of neurons in the superficial laminae and the hamster's superior colliculus. J. Neurosci. 5: 2989-3009.

Moschovakis, A. K., and A. B. Karabelas (1985) Observations on the somatodendritic morphology and axonal trajectory of intracellularly IIRP-labeled efferent ncurons located in the deeper layers of the superior colliculus of the cat. J. Comp. Neurol. 239: 276-308.

Mower, G., A. Gibson, and M. Glickstein (1979) Tectopontine pathway in the cat: Laminar distribution of cells of origin and visual properties of target cells in dorsolateral pontine nucleus. J. Neurophysiol. 42: 1-15.

Nikoletseas, M. M., R. D. Mooney, and R. W. Rhoades (1987) Morphological and physiological characteristics of the superior colliculus cells that project to the lateral posterior nucleus in the golden hamster. Soc. Neurosci. Abstr. 13: 430.

Ogasawara, K., J. G. McHaffie, and B. E. Stein (1984) Two visual corticotectal systems in cat. J. Neurophysiol. 52: 1226-1245.

Rhoades, R. W., and L. M. Chalupa (1978) Functional and anatomical consequences of neonatal visual cortical damage in the superior colliculus of the golden hamster. J. Neurophysiol. 41: 1466-1494.

Rhoades, R. W., and L. M. Chalupa (1980) Effects of neonatal enucleation on receptive-field properties of visual neurons in superior colliculus of the golden hamster. J. Neurophysiol. 43: 595-611.

Rhoades, R. W., R. D. Mooney, A. M. Szczepanik, and B. G. Klein
(1986) Structural and functional characteristics of commissural neurons in the superior colliculus of the hamster. J. Comp. Neurol. 253: 197-215.

Rhoades, R. W., R. D. Mooney, B. G. Klein, M. F. Jacquin, A. M. Szczepanik, and N. L. Chiaia (1987) The structural and functional characteristics of tectospinal neurons in the golden hamster. J. Comp. Neurol. 255: 45l-465.

Schiller, P. H., M. Stryker, M. Cynader, and N. Berman (1974) Response characteristics of single cells in the monkey superior colliculus following ablation or cooling of visual cortex. J. Neurophysiol. 37: 181-194.

Segal, R. L., and R. M. Beckstead (1984) The lateral suprasylvian corticotectal projection in cats. J. Comp. Neurol. 225: 259-275.

Semba, K., P. Masarachia, S. Malamed, M. Jacquin, S. Harris, G. Yang, and M. D. Egger (1983) An electron microscopic study of primary afferent terminals from slowly adapting type I receptors in the cat. J. Comp. Neurol. 221: 466-481.

Sprague, J. M. (1975) Mammalian tectum: Intrinsic organization, afferent inputs, and integrative mechanisms. In Sensorimotor Function of the Midbrain Tectum, Neurosciences Research Program Bulletin, vol. 13, D. Ingle and J. M. Sprague, eds., pp. 204-214, MIT Press, Cambridge, MA.

Stein, B. E. (1978) Nonequivalent visual, auditory and somatic corticotectal influences in cat. J. Neurophysiol. 41: 55-64.

Stein, B. E., and M. O. Arigbede (1972) Unimodal and multimodal response properties of neurons in the cat's superior colliculus. Exp. Neurol. 36: 179-196.

Stewart, D. L., D. Birt, and L. C. Towns (1973) Visual receptive-field characteristics of superior colliculus neurons after cortical lesions in the rabbit. Vision Res. 13: 1965-1977.

Takahashi, Y., and T. Ogawa (1978) Electrophysiological properties of morphologically identified neurons in the rabbit's superior colliculus. Exp. Neurol. 60: 254-266.

Tiao, Y.-C., and C. Blakemore (1976) Functional organization in the superior colliculus of the golden hamster. J. Comp. Neurol. 168: 483504.

Tokunaga, A. (1970) Neuronal structure of the superior colliculus of the rat. J. Chiba Med. Soc. 46: 289-299.

Tokunaga, A., and K. Otani (1976) Dendritic patterns of neurons in the rat superior colliculus. Exp. Neurol. 52: 189-205.

Valverde, F. (1973) The neuropil in superficial layers of the superior colliculus of the mouse. A correlated Golgi and electron microscopic study. Z. Anat. Entwicklung. 142: 117-147.

Victorov, I. V. (1966) Neuronal structure of anterior corpora bigemina in insectivora and rodents. Arkh. Anat. Gistol. Embriol. 51: 82-89.

Wurtz, R. H., and J. E. Albano (1980) Visual-motor function of the primate superior colliculus. Ann. Rev. Neurosci. 3: 189-226. 